American Journal of Agricultural and Biological Sciences 5 (2): 135-142, 2010

ISSN 1557-4989

(C) 2010 Science Publications

\title{
Effect of Feeding Strategy and Carbohydrate Source on Carbohydrate Utilization by Grass Carp (Ctenopharyngodon idella)
}

\author{
${ }^{1}$ L.X. Tian, ${ }^{1}$ Y.J. Liu, ${ }^{2}$ S.S.O. Hung, ${ }^{3}$ D.F. Deng, ${ }^{1}$ H.J. Yang, \\ ${ }^{4}$ J. Niu and ${ }^{1}$ G.Y. Liang \\ ${ }^{1}$ Nutrition Laboratory, Institute of Aquatic Economic Animals, \\ School of Life Science, Sun Yat-sen University, Guangzhou 510275, PR China \\ ${ }^{2}$ Department of Animal Science, University of California-Davis, \\ One Shields Avenue, Davis, California 95616-8521, USA \\ ${ }^{3}$ Oceanic Institute, 41-202 Kalanianaole Hwy. Waimanalo, HI 96795-1820 \\ ${ }^{4}$ South China Sea Fisheries Research Institute, Chinese Academy of Fishery Sciences, \\ Guangzhou, 510300, PR China
}

\begin{abstract}
Problem statement: Feeding strategy is the important factor in aquaculture. Feeding strategy not only could affect the growth performance of grass carp and feed efficiency, but also could affect the quality and environment of water resource. We have proved that glucose was more suitable than starch as the carbohydrate source for grass carp under the restricted feeding frequency. While different feeding strategies may have resulted in the differences in carbohydrate utilization among fish species. No studies have so far been reported that compare the utilization of carbohydrate source in different feeding strategy of grass carp. Approach: A 9-weeks growth trial was conducted to determine the effect of feeding frequency $\left(2,6,12\right.$ and 23 meals day $\left.^{-1}\right)$ and two different carbohydrate source (30\% starch versus $30 \%$ glucose) on the carbohydrate utilization of grass carp (Ctenopharyngodon idella). Both of the two diets with the same feeding rates but with four different feeding frequencies were fed to triplicate groups of grass carp (mean initial wet weight $35.94 \pm 1.86 \mathrm{~g}$ ). Results: In the glucose diet groups, significantly $(\mathrm{p}<0.05)$ higher Final Body Weight (FBW, g), Weight Gain (WG, \%), Specific Growth rate $\left(\mathrm{SGR}, \%\right.$ day $^{-1}$ ), Feed Efficiency (FE, \%), Protein Efficiency Ratio (PER), body lipid and serum Triglyceride (serum TG) were observed in the 6,12 and 23 meals day ${ }^{-1}$ feeding treatments than that in 2 meals day ${ }^{-1}$ feeding treatment, all these indexes were not significantly different among the 6,12 and 23 meals day ${ }^{-1}$ feeding treatments. While in the starch diet groups, FBW, WG and SGR of fish only in the 6 meals day ${ }^{-1}$ feeding treatment were significantly $(p<0.05)$ higher than that of fish in the 2 meals day ${ }^{-1}$ feeding treatment and FBW, WG and SGR of fish in the 12 and 23 meals day ${ }^{-1}$ feeding treatments provided intermediate results and were not significantly different from the 2 and 6 meals day ${ }^{-1}$ feeding treatments. When compared the effects between the glucose and starch diet groups in the same feeding frequency, significantly $(\mathrm{p}<0.05)$ higher FBW, WG, SGR, FE and PER were observed in the glucose than the starch fed grass carp, only body lipid content was significantly higher in grass carp fed the starch than the glucose diets. Conclusion: It suggested that 6 meals day ${ }^{-1}$ feeding was sufficient for the optimal growth and feed efficiency for grass carp on 35.1$37.5 \mathrm{~g}$. Furthermore, the growth performance also suggested that glucose was superior to starch as the carbohydrate source for grass carp under the feeding frequency of 6,12 and 23 meals day ${ }^{-1}$.
\end{abstract}

Key words: Ctenopharyngodon idella, Glucose, Starch, Feeding strategy, Growth

\section{INTRODUCTION}

It is generally believed that the capacity to utilize different carbohydrate sources varies among fish species. Tilapia (Oreochromis niloticus, Anderson et al., 1984), yellowtail (Seriola dumerilii, Furuichi et al., 1986), channel catfish (Icatalurus punctatus, Wilson and Poe, 1987) and hybrid tilapia (Oreochromis niloticus $\times$ O. aureus, Lin et al., 1997) grew better when fed a starch than glucose diet. A review of more recent

Corresponding Author: Y.J. Liu, Nutrition Laboratory, Institute of Aquatic Economic Animals, School of Life Science, Sun Yat-sen University, Guangzhou 510275, P.R. China Tel: +86 2084110789 Fax: +86 2084115896 
studies by Wilson (1994) showed that cooked starch and dextrin are utilized more efficiently than simple sugars by most fish. However, Buhler and Halver (1961) fed Chinook salmon (Epinephelus chlorostigma) with different carbohydrates and found that growth rate decreased with increasing molecular weight of the carbohydrate. Bergot (1979a) fed 150 or $300 \mathrm{~g} \mathrm{~kg}^{-1}$ of glucose or starch to rainbow trout (Oncorhynchus mykiss) and found that $300 \mathrm{~g} \mathrm{~kg}^{-1}$ glucose was optimal. Furuichi and Yong (1982a) found no difference in growth of red sea bream (Pagrosomus major) fed diets with $25 \%$ of either starch, dextrin or glucose. Tian et al. (2004) demonstrated that grass carp grew better when fed a glucose than starch diet. All these reports are from different laboratories and were conducted under different experimental conditions, so some differences were found although in the same fish species. Hung et al. (1989) found that white sturgeon (Acipenser transmontunus) utilized glucose and maltose more efficiently than fructose, sucrose, lactose, dextrin or starch, while Lin et al. (1997) found that white sturgeon grew better when fed a starch than glucose diet. No consistent results about different complexities of carbohydrate utilization among fish species of different food habits have been achieved. Furthermore, the differences in carbohydrate utilization among fish species may have resulted from different feeding strategies because only one feeding strategy was used in the above studies except that Lin et al. (1997) compared the different feeding strategies.

Inappropriate feeding practices in aquaculture may lead to feed being wasted or to insufficient feed being provided, resulting in higher production costs (Mihelakakis et al., 2002) and contamination of the aquatic environment ( $\mathrm{Ng}$ et al., 2000), moreover, there is evidence that prolonged feeding periods also decreases digestive efficiency as it increases evacuation rate (Rabe and Brown, 2000). Furthermore, the consumption of excess food not only decreases absorption efficiency but also increases the energy required for digestion, which directly influences the use of the nutrients in the feed for growth performance of fish (Mihelakakis et al., 2002). Conversely, a restricted feeding strategy will impair the utilization of carbohydrate and slow growth (Lin et al., 1997). On the other hand, efficient feeding strategy provides better growth and production (Cho et al., 2003; Eroldogan et al., 2004). An optimum feeding strategy is helpful to minimize the feed loss, reduce water pollution and decrease cost of aquaculture production. In general, feed management or feeding techniques have two main objectives, one is to encourage rapid and positive consumption and thus reducing leaching of nutrients wastage, the other is to provide greater potential for growth by minimizing the metabolic costs. Improved growth performance by increasing meal frequency from 2-6 day ${ }^{-1}$ has been observed in rainbow trout (Bergot, 1979a), common carp (Murai et al., 1983) and hybrid tilapia (Tung and Shiau, 1991) when they were fed glucose and starch diets.

Grass carp is very popular in China because of its fast growth, good taste and firm meat texture (Lin, 1991; Tian et al., 2004). Tian et al. (2004) has conducted to compare the utilization of different carbohydrate source in grass carp, but it is also important to establish an appropriate feeding management program. Nutritionally well-balanced diets and the suitable feeding strategy are the main requirements for successful culture operations (Bascinar et al. 2007). While no studies have so far been reported that compare the utilization of carbohydrate source in different feeding strategy of grass carp. The objective of this study was to determine the effect of feeding strategy and carbohydrate source on the growth performance of grass carp.

\section{MATERIALS AND METHODS}

Diet preparation: Formulation and composition of the experimental diets are shown in Table 1. Suppliers for major ingredients were all in PR China and they were: Casein (Shanghai Bright Diary Company Ltd., Shanghai); gelatin (Guangzhou Huankai Microbial Science Technology Company Ltd., Guangzhou); glucose (Guangzhou Chemical Reagent Factory, Guangzhou); cornstarch (Langfang City Starch Factory, Langfang, Hebei Province); corn oil (Panyu Hexing Oils Company Ltd., Uangzhou) and cellulose (Guangzhou Shiqiao Pharmaceutical Factory, Guangzhou). The dry ingredients were mixed (A-200T Mixer Bench Model unit, Russell Food Equipment Ltd., Ottawa, Ontario, Canada) for $15 \mathrm{~min}$; corn oil and fish oil were then added and mixed for another $15 \mathrm{~min}$. Water $\left(40 \mathrm{~mL} \mathrm{~kg}^{-1}\right.$ dry ingredients mixture for glucose diet and $300 \mathrm{~mL} \mathrm{~kg}^{-1}$ dry ingredients mixture for starch diet) was added and mixed for another $15 \mathrm{~min}$. The wet mixture was then pelleted into $1.5 \mathrm{~mm}$ pellets (Institute of Chemical Engineering, South China University of Technology, Guangzhou, PR China), air-dried at room temperature for $24 \mathrm{~h}$ and stored at $-20^{\circ} \mathrm{C}$ until used.

Supply and maintenance of fish: Grass carp juveniles were obtained from the earthen ponds of our hatchery, they were disinfected in an 8 min prophylactic bath that contained $5 \mu \mathrm{L}$ of a commercial grade formalin (36\% formaldehyde) per liter of water before they were transferred to the aquaria (Piper et al., 1982). 
Table 1: Ingredients and proximate composition of the two experimental diets $\left(\mathrm{g} \mathrm{kg}^{-1}\right.$ dry matter)

\begin{tabular}{|c|c|c|}
\hline & Glucose diet & Starch diet \\
\hline \multicolumn{3}{|l|}{ Formulation } \\
\hline Casein & 320.0 & 320.0 \\
\hline Gelatin & 80.0 & 80.0 \\
\hline Glucose & 300.0 & 0.0 \\
\hline Corn starch & 0.0 & 300.0 \\
\hline Corn oil & 30.0 & 30.0 \\
\hline Mixed fish oil ${ }^{\mathrm{a}}$ & 30.0 & 30.0 \\
\hline Vitamin mix ${ }^{\mathrm{b}}$ & 20.0 & 20.0 \\
\hline Mineral $\mathrm{mix}^{\mathrm{c}}$ & 80.0 & 80.0 \\
\hline Cellulose & 119.0 & 119.0 \\
\hline Ascorbic acid phosphate ester & 10.0 & 10.0 \\
\hline Choline chloride ${ }^{\mathrm{e}}$ & 6.0 & 6.0 \\
\hline $\mathrm{Cr}_{2} \mathrm{O}_{3}$ & 5.0 & 5.0 \\
\hline \multicolumn{3}{|l|}{ Proximate composition } \\
\hline Moisture & 115.4 & 113.5 \\
\hline Crude protein & 369.6 & 362.1 \\
\hline Crude lipid & 55.8 & 58.1 \\
\hline Carbohydrate & 241.5 & 254.2 \\
\hline Ash & 34.3 & 33.6 \\
\hline
\end{tabular}

${ }^{a}$ : Fish oil: mixed fish oil supplied by Bakels Edible Oils Ltd., Mt. Maunganui, New Zealand; ${ }^{\text {b: }}$ Vitamin mix contained (mg. $\mathrm{kg}^{-1}$ of diet): thiamine $\mathrm{HNO}_{3}, 50$; riboflavin, 50; vitamin A, 25000IU; vitamin E, 400; vitamin $\mathrm{D}_{3}$, $24000 \mathrm{IU}$ (Roche Taishan, Shanghai, PR China Vitamin Products Ltd., Shanghai, PR China); menadione, 40 (Zhejiang Brother chemical Company Ltd., Zhejiang Province, PR China); pyridoxine HCl, 40 (HuBei Xian ning Second Pharmaceutical Factory, Xian ning, Hubei Province, PR China); cyanocobalamin, 0.1 (Junchi Biological Technology Co., Ltd, Tianjing, PR China); biotin, 6 (Sumitomo chemical Co., Ltd., Osaka Japan); calcium pantothenate, 100 (Dahchi Pharmaceutical Co., Ltd , Tokyo, Japan); folic acid, 15 (Jinan Xinfa Pharmaceutical Co., Ltd. Jinan, Shandong Province, PR China); niacin, 200 (Lonza Guangzhou Ltd. Co. Guangzhou, Guangdong province, PR China); inositol, 2000 (Shanghai Yiran Industrial Limited Company, Shanghai, PR China) and cellulose was used as a carrier; ' : Mineral mix: $\left(\mathrm{g} \mathrm{kg}^{-1}\right.$ diet): calcium biphosphate, 9.8; calcium lactate, 37.9; sodium chloride, 2.6; potassium sulfate, 13.1; potassium chloride, 5.3; ferrous sulfate, 0. 9; ferric citrate, 3.1; magnesium sulfate, 3.5 ; zinc sulfate, 0.04 ; manganese sulfate, 0.03 ; cupric sulfate, 0.02 ; cobalt chloride, 0.03 ; potassium iodide, 0.002 and cellulose 42 . All minerals were supplied by Guangzhou Chemical Reagent Factory, except that calcium Lactate was supplied by Yinchuan Jintaiyang Calcium lactate Co., Ltd, Yinchuan, Ningxia Province, PR China; ${ }^{d}$ : Supplied by Beijing Sunpu Biochemical technology Company Ltd., Beijing, PR China; ${ }^{\text {e: }}$ Supplied by Tianjing Bohai Veterinary Medicine Factory, Tianjing, PR China

The fish were acclimated to the experimental conditions for 4 weeks. When the experiment began, all the fish in tanks were pooled together. Six hundred health fish with similar body weight were selected from them and distributed randomly into the 24-tank system with 25 fish per tank, each of the fiberglass tanks $(98 \times 48 \times 42 \mathrm{~cm}$, water volume of $200 \mathrm{~L})$ connected to recirculating systems with a common reservoir of $600 \mathrm{~L}$. Incoming water from Guangzhou Municipal and recirculation water was oxygenated, passed though an artificial sponge (3 cm thickness), coral-sand $(25 \mathrm{~cm}$ thickness) and active-carbon filter (25 $\mathrm{cm}$ thickness) to remove chlorine and biological wastes and the water exchange rate was $10 \mathrm{~L} \mathrm{~min}^{-1}$ $\operatorname{tank}^{-1}$. The fish were weighed and the differences of total weight among tanks were less than $5 \%$. The initial body weights were $35.94 \pm 1.86 \mathrm{~g}$.

The feeding rate is $5.0 \%$ body weight per day of diets with three replicate tanks per diet. Four feeding frequencies were used in this study (two, six, twelve and twenty-three times per day), the feeding frequencies were 2 times (09:00 and 15:00 h), 6 times (09:00, 11:00, 13:00, 15:00, 17:00 and 19:00 h), 12 times (09:00, 10:00, 11:00, 12:00, 13:00, 14:00, 15:00, 16:00, 17:00, 18:00, 19:00 and 20:00 h) and 23 times (09:00, 10:00, 11:00, 12:00, 13:00, 14:00, 15:00, 16:00, 17:00, 18:00, 19:00, 20:00, 21:00, 22:00, 23:00, 00:00, 01:00, 02:00, 03:00, 04:00, 05:00, 06:00 and 07:00 h) per day, respectively. The feeding frequencies of 2 times, 6 times and 12 times per day were fed by hand and the other feeding frequency of 23 times per day was fed by the automatic feeders to distribute fixed quantities of feed at specific times.

The experiments lasted nine weeks. The fish in each tank were weighed as a whole once every 14 days and the feeding rate adjusted accordingly thereafter. Average daily water temperature, dissolved oxygen, $\mathrm{pH}$ and ammonia were $28.9 \pm 0.5^{\circ} \mathrm{C}, 5.0 \pm 1.3 \mathrm{mg} \mathrm{L^{-1 }}$, $7.6 \pm 0.1$ and $30 \pm 30 \mu \mathrm{g} \mathrm{L}^{-1}$, respectively.

Sample collection and chemical analyses: At the end of the feeding trial, fish were fasted for $24 \mathrm{~h}$ and then weighed. Five fish were randomly captured from each tank for whole body chemical analysis. Another five fish were randomly captured and killed by immediately severing the spinal cord for analysis of blood. Blood was collected from the heart into tubes and serum separated by high speed centrifugation $\left(97000 \times \mathrm{g}, 15 \mathrm{~min}, 4^{\circ} \mathrm{C}\right)$. A fraction of serum was stored at $-20^{\circ} \mathrm{C}$ until analysis.

Diets and body composition were analyzed in triplicate for proximate composition. Moisture, crude protein, crude lipid and ash were determined using standard methods (Association of Official Analytical Chemists, 1984). Moisture was determined by drying in an oven at $105^{\circ} \mathrm{C}$ for $24 \mathrm{~h}$. Crude protein $(\mathrm{N} \times 6.25)$ was analyzed by the Kjeldahl method after acid digestion (1030-Auto-analyzer, Tecator, Sweden). Crude lipid was determined by the ether-extraction method by Soxtec System HT (Soxtec System HT6, Tecator, Sweden) and crude ash by incineration in a muffle furnace at $550^{\circ} \mathrm{C}$ for $24 \mathrm{~h}$. Serum glucose and serum triglyceride were assayed by enzymic procedure (glucose oxidase method and glycerophosphate oxidase method, respectively) using a serum glucose and triglyceride determination kits (Shanghai Long March Medical Science Co., Ltd. Shanghai, China). 
Statistical analysis: Data were analyzed by two-way factorial ANOVA to test the effects of carbohydrate source and feeding strategy and their interaction. In the absence of interactions, one-way ANOVA of single factors was performed. Duncan (1955) multiple range test was used as significant $(\mathrm{p}<0.05)$ differences were found in one-way ANOVA test. Statistical analyses were done using the SPSS program (Version 13.0).

\section{RESULTS}

Feeding and growth parameters: Growth performance (FBW, WG, SGR, FE and PER) in grass carp fed the experimental diets are shown in Table 2. There was no mortality in the experiment. In the glucose diet groups, significantly $(\mathrm{p}<0.05)$ lower FBW, WG, SGR, FE and PER were observed in the 2 meals day ${ }^{-1}$ feeding than that in the 6,12 and 23 meals day $^{-1}$ feeding, all these data were not significantly different among the 6,12 and 23 meals day $^{-1}$ feeding treatments. While in the starch diet groups, only FBW, WG and SGR of fish in the 6 meals $\mathrm{day}^{-1}$ feeding treatment were significantly $(\mathrm{p}<0.05)$ higher than that of fish in the 2 meals day ${ }^{-1}$ feeding treatment and FBW, WG and SGR of fish in the 12 and
23 meals day ${ }^{-1}$ feeding treatments provided intermediate results and were not significantly different from the 2 and 6 meals day ${ }^{-1}$ feeding treatments. When compared the growth performance between the glucose and starch diet groups in the same feeding frequency, significantly $(\mathrm{p}<0.05)$ higher FBW, WG, SGR, FE and PER were observed in the glucose than the starch fed grass carp.

Body composition: Body composition (moisture, crude protein, crude fat and ash) in grass carp fed the experimental diets are shown in Table 3. In the glucose diet groups, significantly $(\mathrm{p}<0.05)$ higher body moisture but lower crude protein, crude fat and ash were observed in the 2 meals day ${ }^{-1}$ feeding than that in the 6,12 and 23 meals day ${ }^{-1}$ feeding, all these data were not significantly different among the 6,12 and 23 meals day ${ }^{-1}$ feeding treatments. While in the starch diet groups, no significant differences were found in moisture, crude protein, crude fat and ash. When compared the body composition between the glucose and starch diet groups in the same feeding frequency, significantly $(p<0.05)$ lower body crude fat but higher moisture was found in grass carp fed the glucose than the starch diets, while no significant differences were found in body crude protein and ash.

Table 2: Effect of feeding strategy and carbohydrate source on the growth performance of grass carp

\begin{tabular}{llllllll}
\hline Carbohydrate source & Feeding strategy & IBW & FBW & WG & SGR & FE & PER \\
\hline Glucose & 2 & $35.6 \pm 0.5$ & $115.8 \pm 2.6^{\mathrm{ab}}$ & $225.6 \pm 11.9^{\mathrm{ab}}$ & $1.87 \pm 0.06^{\mathrm{ab}}$ & $64.75 \pm 3.71^{\mathrm{ab}}$ & $1.75 \pm 0.10^{\mathrm{ab}}$ \\
& 6 & $36.0 \pm 0.7$ & $146.6 \pm 5.0^{\mathrm{d}}$ & $307.5 \pm 5.9^{\mathrm{d}}$ & $2.23 \pm 0.02^{\mathrm{d}}$ & $76.29 \pm 0.59^{\mathrm{c}}$ & $2.06 \pm 0.02^{\mathrm{c}}$ \\
& 12 & $35.7 \pm 0.5$ & $139.0 \pm 2.8^{\mathrm{cd}}$ & $289.3 \pm 5.4^{\mathrm{cd}}$ & $2.16 \pm 0.02^{\mathrm{cd}}$ & $71.47 \pm 1.93^{\mathrm{bc}}$ & $1.93 \pm 0.05^{\mathrm{bc}}$ \\
Starch & 23 & $36.6 \pm 0.9$ & $151.5 \pm 7.9^{\mathrm{d}}$ & $313.9 \pm 21.4^{\mathrm{d}}$ & $2.25 \pm 0.08^{\mathrm{d}}$ & $74.71 \pm 2.33^{\mathrm{c}}$ & $2.02 \pm 0.06^{\mathrm{c}}$ \\
& 2 & $35.6 \pm 0.1$ & $107.1 \pm 2.7^{\mathrm{a}}$ & $201.2 \pm 7.7^{\mathrm{a}}$ & $1.75 \pm 0.04^{\mathrm{a}}$ & $58.62 \pm 0.50^{\mathrm{a}}$ & $1.63 \pm 0.02^{\mathrm{a}}$ \\
& 6 & $36.9 \pm 0.1$ & $128.8 \pm 0.7^{\mathrm{bc}}$ & $250.0 \pm 2.2^{\mathrm{bc}}$ & $1.99 \pm 0.01^{1 \mathrm{c}}$ & $64.77 \pm 0.87^{\mathrm{ab}}$ & $1.79 \pm 0.03^{\mathrm{ab}}$ \\
& 12 & $36.3 \pm 0.7$ & $122.1 \pm 11.8^{\mathrm{abc}}$ & $235.7 \pm 28.9^{\mathrm{ab}}$ & $1.91 \pm 0.14^{\mathrm{ab}}$ & $58.98 \pm 3.33^{\mathrm{a}}$ & $1.63 \pm 0.09^{\mathrm{a}}$ \\
ANOVA (p-values) & 23 & $36.6 \pm 0.6$ & $126.5 \pm 5.5^{\mathrm{bc}}$ & $246.5 \pm 19.6^{\mathrm{abc}}$ & $1.97 \pm 0.10^{\mathrm{bc}}$ & $65.61 \pm 3.73^{\mathrm{ab}}$ & $1.81 \pm 0.10^{\mathrm{ab}}$ \\
Source & & & & & & & \\
Carbohydrate source (A) & 1 & & & & & & \\
Feeding strategy (B) & 3 & & 0.001 & 0.000 & 0.000 & 0.000 & 0.000 \\
A×B & 3 & & 0.001 & 0.002 & 0.002 & 0.007 & 0.008 \\
\hline Var. & & & 0.596 & 0.562 & 0.699 & 0.592 & 0.562 \\
\hline
\end{tabular}

Values are means \pm SEM of three replicates. Values in the same column for each type of experiment with different letters are significant different $(\mathrm{p}<0.05)$. IBW $\left(\mathrm{g} \mathrm{fish}^{-1}\right)$ : Initial body wet weight $\left(\mathrm{g} \mathrm{fish}^{-1}\right)$. FBW $\left(\mathrm{g} \mathrm{fish}^{-1}\right)$ : Final body wet weight $\left(\mathrm{g} \mathrm{fish}^{-1}\right)$; WG $(\%)$ : Weight gain $=100 \times(\mathrm{final}$ body weight-initial body weight)/initial body weight; SGR $\left(\% \mathrm{day}^{-1}\right)$ : Specific growth ratio $=100 \times(\ln$ final wt.-ln initial wt.)/total of experimental days; FE (\%): Feed Efficiency $(\%)=100 \%$ (total weight gain/total dry feed); PER: Protein Efficiency Ratio = total weight gain/total protein intake

Table 3: Effect of feeding strategy and carbohydrate source on body composition of grass carp

\begin{tabular}{|c|c|c|c|c|c|}
\hline $\begin{array}{l}\text { Carbohydrate } \\
\text { source }\end{array}$ & $\begin{array}{l}\text { Feeding } \\
\text { strategy }\end{array}$ & Moisture & $\begin{array}{l}\text { Crude protein } \\
\left(\mathrm{g} \mathrm{kg}^{-1} \text { wet } \mathrm{wt}\right)\end{array}$ & $\begin{array}{l}\text { Crude lipid } \\
\text { ( } \mathrm{g} \mathrm{kg}^{-1} \text { wet wt) }\end{array}$ & $\begin{array}{l}\text { Ash } \\
\left(\mathrm{g} \mathrm{kg}^{-1} \text { wet wt }\right)\end{array}$ \\
\hline \multirow{4}{*}{ glucose } & 2 & $749.7 \pm 5.2^{\mathrm{d}}$ & $151.0 \pm 1.5^{\mathrm{a}}$ & $59.9 \pm 2.5^{\mathrm{a}}$ & $29.5 \pm 0.5^{\mathrm{a}}$ \\
\hline & 6 & $713.2 \pm 7.5^{\mathrm{c}}$ & $159.0 \pm 4.1^{\mathrm{abc}}$ & $89.6 \pm 3.1^{\mathrm{b}}$ & $31.9 \pm 1.5^{\mathrm{abc}}$ \\
\hline & 12 & $718.2 \pm 4.2^{\mathrm{c}}$ & $159.8 \pm 1.5^{\mathrm{bc}}$ & $93.9 \pm 5.9^{\mathrm{bc}}$ & $32.6 \pm 0.3^{\mathrm{bc}}$ \\
\hline & 23 & $704.3 \pm 14.1^{\mathrm{bc}}$ & $165.3 \pm 4.0^{\mathrm{c}}$ & $92.7 \pm 5.0^{\mathrm{b}}$ & $32.8 \pm 1.1^{\mathrm{c}}$ \\
\hline \multirow[t]{4}{*}{ Starch } & 2 & $670.1 \pm 9.2^{\mathrm{a}}$ & $153.0 \pm 3.8^{\mathrm{ab}}$ & $117.8 \pm 11.4^{\mathrm{cd}}$ & $31.8 \pm 0.3^{\text {abc }}$ \\
\hline & 6 & $687.6 \pm 8.5^{\mathrm{ab}}$ & $158.3 \pm 1.5^{\mathrm{abc}}$ & $120.6 \pm 7.8^{\mathrm{d}}$ & $32.3 \pm 1.0^{\mathrm{bc}}$ \\
\hline & 12 & $679.3 \pm 6.6^{\mathrm{ab}}$ & $161.3 \pm 2.6^{\mathrm{bc}}$ & $133.2 \pm 16.9^{\mathrm{d}}$ & $30.2 \pm 0.7^{\mathrm{ab}}$ \\
\hline & 23 & $693.6 \pm 7.8^{\mathrm{abc}}$ & $164.8 \pm 1.2^{\mathrm{c}}$ & $124.5 \pm 0.4^{\mathrm{d}}$ & $32.0 \pm 0.3^{\mathrm{abc}}$ \\
\hline \multicolumn{6}{|l|}{ ANOVA (p-values) } \\
\hline Source & d.f. & & & & \\
\hline Carbohydrate source (A) & 1 & 0.000 & 0.763 & 0.000 & 0.836 \\
\hline Feeding strategy (B) & 3 & 0.129 & 0.271 & 0.040 & 0.429 \\
\hline $\mathrm{A} \times \mathrm{B}$ & 3 & 0.014 & 0.005 & 0.363 & 0.044 \\
\hline
\end{tabular}

Values are means \pm SEM of three replicates. Values in the same column for each type of experiment with different letters are significant different $(\mathrm{p}<0.05)$ 
Am. J. Agri. \& Biol. Sci., 5 (2): 135-142, 2010

Table 4: Effect of feeding strategy and carbohydrate source on morphometry of grass carp

\begin{tabular}{llll}
\hline Carbohydrate source & Feeding strategy & Hepatopancreas-to-body ratio & Mesenteric fat index \\
\hline Glucose & 2 & $1.98 \pm 0.08^{\mathrm{a}}$ & $1.36 \pm 0.14^{\mathrm{a}}$ \\
& 6 & $2.11 \pm 0.17^{\mathrm{b}}$ & $1.85 \pm 0.27^{\mathrm{ab}}$ \\
& 12 & $2.17 \pm 0.01^{\mathrm{bc}}$ & $2.13 \pm 0.02^{\mathrm{bc}}$ \\
Starch & 23 & $2.42 \pm 0.11^{\mathrm{bc}}$ & $2.75 \pm 0.09^{\mathrm{c}}$ \\
& 2 & $2.27 \pm 0.07^{\mathrm{abc}}$ & $3.74 \pm 0.25^{\mathrm{c}}$ \\
& 6 & $2.40 \pm 0.05^{\mathrm{bc}}$ & $3.69 \pm 0.26^{\mathrm{d}}$ \\
ANOVA (p-values) & 12 & $2.32 \pm 0.10^{\mathrm{bc}}$ & $2.55 \pm 0.46^{\mathrm{bc}}$ \\
Source & 23 & $2.18 \pm 0.11^{\mathrm{abc}}$ & \\
Carbohydrate source (A) & & 0.000 \\
Feeding strategy (B) & 1 & 0.102 & 0.020 \\
A $\times$ B & 3 & 0.343 & 0.005 \\
\hline Values are means \pm S.E.M of three replicates. Values in the same column for each type of experiment with different letters are significant different \\
(p<0.05); Hepatopancreas-to-body ratio $=100 \times$ hepatopancreas weight / whole body weight; Mesenteric fat index $=100 \times$ mesenteric fat \\
weight/whole body weight
\end{tabular}

Table 5: Effect of feeding strategy and carbohydrate source on serum glucose and TG levels of grass carp

\begin{tabular}{llll}
\hline Carbohydrate source & Feeding strategy & Serum glucose $\left(\mathrm{mmol} \mathrm{L}^{-1}\right)$ & Serum TG $\left(\mathrm{mmol} \mathrm{L}^{-1}\right)$ \\
\hline Glucose & 2 & $7.33 \pm 1.27$ & $1.55 \pm 0.09^{\mathrm{a}}$ \\
& 6 & $6.94 \pm 0.54$ & $2.27 \pm 0.15^{\mathrm{b}}$ \\
& 12 & $7.17 \pm 1.10$ & $2.32 \pm 0.21^{\mathrm{b}}$ \\
Starch & 23 & $6.33 \pm 0.66$ & $2.50 \pm 0.28^{\mathrm{b}}$ \\
& 2 & $7.22 \pm 1.19$ & $2.20 \pm 0.13^{\mathrm{b}}$ \\
& 6 & $7.32 \pm 1.13$ & $2.53 \pm 0.19^{\mathrm{b}}$ \\
ANOVA (p-values) & 12 & $7.11 \pm 0.59$ & $2.49 \pm 0.16^{\mathrm{b}}$ \\
Source & 23 & $7.06 \pm 0.45$ & $2.56 \pm 0.28^{\mathrm{b}}$ \\
Carbohydrate source (A) & & & \\
Feeding strategy (B) & d.f. & 0.622 & 0.023 \\
AxB & 1 & 0.900 & 0.006 \\
\hline
\end{tabular}

Values are means \pm SEM of three replicates. Values in the same column for each type of experiment with different letters are significant different (p<0.05); TG: Triglyceride

Morphometry: The morphometry index (HSI: Hepatopancreas-to-body ratio, MFI: Mesenteric Fat Index) in grass carp fed the experimental diets are shown in Table 4. HSI was not affected by both feeding strategy and carbohydrate source. While MFI increased with increasing the feeding frequency whether in glucose or starch diet treatment. When compared MFI between the glucose and starch diet treatments in the same feeding frequency, significantly lower MFI was found in grass carp fed the glucose than the starch diet.

Serum parameters: The serum parameters (serum glucose and serum triglyceride) in grass carp fed the experimental diets are shown in Table 5. In the glucose diet groups, only significantly $(\mathrm{p}<0.05)$ lower serum triglyceride was observed in the 2 meals day ${ }^{-1}$ feeding than in the 6,12 and 23 meals day ${ }^{-1}$ feeding, this data was not significantly different among the 6,12 and 23 meals day ${ }^{-1}$ feeding treatments. While in the starch diet groups, no significant differences were found in serum glucose and serum triglyceride. The serum glucose was not affected by both feeding strategy and carbohydrate source.

\section{DISCUSSION}

In the present experiment, the FBW, WG, SGR, FE and PER were significantly higher in the glucose fed than starch fed groups whether the feeding frequency was 6,12 or 23 meals day $^{-1}$. These results are in accordance with the previous findings of chinook salmon, white sturgeon and rainbow trout (Buhler and Halver, 1961; Hung et al., 1989; Bergot, 1979b). However, the results of the present experiment are different from those reported for tilapia and flounder (Anderson et al., 1984; Lee et al., 2003), higher growth and protein utilization of fish fed the diets containing polysaccharides than those of fish fed diets containing mono- and disaccharides. Moreover, the weight gain of red sea bream was not affected by different dietary carbohydrate sources such as glucose, dextrin and starch (Furuichi and Yone, 1982a). Dietary carbohydrate utilization by fish varies and appears to be 
related to the complexity of carbohydrate (Wilson, 1994). Although the mechanism responsible for the observed differences in carbohydrate utilization is not known, Pieper and Pfeffer (1980) considered that the lower growth performance of fish fed the glucose diet was probably due to rapid absorption of glucose in the gut. And the excess absorbed glucose may be cleared from blood before body cells can utilize it efficiently (Furuichi and Yone, 1982b). The different ability to utilize dietary carbohydrate by fish may be due to differences in fish species, dietary composition of the experimental diets and culture conditions. Regarding the results of the present experiment, it showed that though the assimilation of glucose was better than starch in grass carp, it did not appear the 'negative physiological effects' caused by glucose saturation as suggested by Pieper and Pfeffer (1980). Moreover, Tian et al. (2004) showed that grass carp could utilize the rapid absorbed dietary glucose directly as an energy source, so it may be used to spare a part of protein in the diet. It should be the main reason that growth and feed utilization of grass carp fed the glucose diet in the present study were higher than those fed the starch diet.

As previously reported (Murai et al., 1983; Tung and Shiau, 1991; Lin et al., 1997), growth performance of fish could be improved by increasing the feeding frequency. Murai et al. (1983) indicated the growth performance of carp fed the starch diet was higher than that fed the glucose diet when the feeding frequency was 2 meals day ${ }^{-1}$, but the growth performance of carp was not affected by different dietary carbohydrate sources such as glucose, maltose, dextrin and starch when the feeding frequency was 6 meals day ${ }^{-1}$. This is in accordance with Furuichi and Yone (1982b), who detected that increasing the feeding frequency could decrease the overloading of metabolic capacity of glucose in carp. Lin et al. (1997) indicated one of the major reasons of the lower performances in the 2 meals day $^{-1}$ feeding than the continuous feeding is the slownibbling habit sturgeon (eat very small in each meal and eat very slowly). Another reason of the lower performance in the 2 meals day $^{-1}$ feeding than the continuous feeding may have resulted from the overloading of metabolic capacity in the glucose fed sturgeon and digestibility capacity in the starch fed sturgeon. The overloading led to lower lipogenesis by the lower body lipid content in the 2 meals day ${ }^{-1}$ feeding than the continuous feeding sturgeon as shown in Lin et al. (1997). This means that the utilization of carbohydrate as the energy could be improved by increasing the feeding frequency under the restricted feeding rate. It could be indicated from the results of our present experiment, the growth performance of grass carp were significantly increased with the increase of feeding frequency from 2-6 meals day ${ }^{-1}$ in both glucose and starch diet groups.

Optimal feeding strategy could reduce excretory losses of nitrogen, optimize the amount of nutrients and metabolic fuel made available for growth. Optimal feeding frequency may vary depending on species, age, size, husbandry and feed quality (Goddard, 1996). Kono and Nose (1971) suggested that the optimum feeding frequency of the no-stomach fish, such as the carp and goldfish, is not more than 12 meals day ${ }^{-1}$. Piper et al. (1982) suggested three times daily feeding for 15.1-45.0 $\mathrm{g}$ rainbow trout fingerlings is suitable. Bascinar et al. (2007) indicated that three times daily feeding is better than one and two times daily feeding in growth performance for 155-211 g Black Sea trout. In the present experiment, the results demonstrate that grass carp do not require constant feeding, a feeding frequency of 6 meals day ${ }^{-1}$ caused a significant increase in growth performance compared to 2 meals day ${ }^{-1}$. While Increasing feeding frequency above 6 meals day ${ }^{-1}$ did not result in a further increase in growth performance. Based on the results, a feeding frequency of 6 meals day $^{-1}$ is suggested to be enough for achieving optimum growth rate and feed efficiency for grass carp on 35.1-37.5 g.

Body composition was significantly influenced by feeding frequency in the glucose diet groups but not in the starch diet groups (Table 3). Only body lipid content was significantly affected by both carbohydrate source and feeding frequency. Significantly $(\mathrm{p}<0.05)$ lower lipid content was found in grass carp fed the glucose than the starch diets under the same frequency. This is in accordance with Murai et al. (1983), who detected that the lipid content of carp fed glucose diet is lower than that of fish fed starch diet. It may be the reason that starch increases the fat deposition in grass carp more easily than glucose. In the present experiment, the higher body lipid content was concentrated mostly in the mesentery because of a significantly higher mesenteric fat index in grass carp fed the starch as opposed to the glucose diet. While Hutchins et al. (1998) and Rawles and Gatlin (1998) did not observed any difference in the intraperitoneal fat ratio in striped bass Morone saxatilis and sunshine bass (female white bass $M$. chrysops $\times$ male striped bass) fed a glucose, maltose, or dextrin diet. In the present experiment, the body lipid content of fish fed the glucose diet increased with increasing the feeding frequency though no significant differences were observed among the 6, 12 and 23 meals day ${ }^{-1}$ feeding treatments. Other studies 
also report that an increase of feeding frequency in several species of fish led to a high body lipid content (Grayton and Beamish, 1977; Thia-Eng and Seng-Keh, 1978; Kayano et al., 1993). It might indicate that an increase in feeding frequency increased body lipid content probably because surplus feed consumed by fish was converted into body fat (Cho et al., 2003). Meanwhile, in the present experiment, a tendency was found that the lipid content of fish fed the starch diet increased with increasing the feeding frequency though no significant differences were observed among groups. The exact mechanism of lipid deposition and distribution in grass carp fed different carbohydrates is unknown and more studies are needed.

\section{CONCLUSION}

In conclusion, this experiment showed that under conditions of restricted feeding rate, feeding frequency had a significant effect on weight gain, feed efficiency, protein efficiency ratio and lipid content of the fish. Therefore, based on the results, it suggested that 6 meals day $^{-1}$ feeding was sufficient for the optimal growth and feed efficiency for grass carp on 35.1-37.5 g. Furthermore, the growth performance also suggested that glucose was superior to starch as the carbohydrate source for grass carp under the feeding frequency of 6,12 and 23 meals day ${ }^{-1}$.

\section{ACKNOWLEDGEMENT}

The research is supported by the Chinese National Science Foundation (Grant number 39970576).

\section{REFERENCES}

Anderson, J., A.J. Jackson, A.J. Matty and B.S. Copper, 1984. Effects of dietary carbohydrate and fiber on the tilapia (Oreochromis niloticus). Aquaculture, 37: 303-314. DOI: 10.1016/0044-8486(84)90296-5

Association of Official Analytical Chemists, (AOAC), 1984. Official Methods of Analysis. 14th Edn., AOAC, Arlington, VA., pp: 114.

Bascinar, N., E. Cakmak, Y. Cavdar and N. Aksungur, 2007. The effect of feeding frequency on growth performance and feed conversion rate of black sea trout (Salmo trutta labrax Pallas, 1811). Turk. J. Fish. Aquat. Sci., 7: 13-17. http://www.trjfas.org/pdf/issue_7_1/13_17.pdf

Bergot, F., 1979a. Carbohydrate in rainbow trout diets: Effects of the level and source of carbohydrate and the number of meals on growth and body composition. Aquaculture, 18: 157-167. DOI: 10.1016/0044-8486(79)90028-0
Bergot, F., 1979b. Effects of dietary carbohydrates and of their mode of distribution on glycaemia in rainbow trout (Salmo gairdneri Richardson). Comp. Biochem. Physiol., 64A: 543-547. DOI: 10.1016/0300-9629(79)90581-4

Buhler, D.R. and J.E. Halver, 1961. Nutrition of Salmonoid fishes. IX. Carbohydrate requirements of Chinook salmon. J. Nutr., 74: 307-318. http://jn.nutrition.org/cgi/content/abstract/74/3/307

Cho, S.H., Y.S. Lim, J.H. Lee, J.K. Lee, S. Park and S.M. Lee, 2003. Effects of Feeding Rate and Feeding Frequency on Survival, Growth and Body Composition of Ayu Post-Larvae Plecoglossus altivelis. J. World. Aquacult. Soc., 34: 85-91. http://d.wanfangdata.com.cn/NSTLQK_NSTL_QK 6869238.aspx

Duncan, D.B., 1955. Multiple-range and multiple F tests. Biometrics, 11: 1-42. http://www.jstor.org/stable/3001478

Eroldogan, O.T., M. Kumlu and M. Aktas, 2004. Optimum feeding rates for European sea bass Dicentrarchus labrax L. reared in seawater and freshwater. Aquaculture, 231: 501-515. DOI: 10.1016/j.aquaculture.2003.10.020

Furuichi, M. and Y. Yone, 1982a. Availability of carbohydrate in nutrition of carp and red sea bream. Bull. Jap. Sot. Sci. Fish., 48: 945-948. http://rms1.agsearch.agropedia.affrc.go.jp/contents/ JASI/pdf/society/25-2965.pdf

Furuichi, M. and Y. Yone, 1982b. Change in activities of hepatic enzymes related to carbohydrate metabolism of fishes in glucose and insulinglucose tolerance tests. Bull. Jap. Soc. Sci. Fish., 48: 463-466.

http://rms1.agsearch.agropedia.affrc.go.jp/contents/ JASI/pdf/society/24-4008.pdf

Furuichi, M., H. Taira and Y. Yone, 1986. Availability of carbohydrate in nutrition of yellowtail. Bull. Jap. Sot. Sci. Fish., 52: 99-102. http://cat.inist.fr/?aModele $=$ afficheN\&cpsidt $=7944235$

Goddard, S., 1996. Feed Management in Intensive Aquaculture. Chapman and Hall, New York, USA., ISBN: 0-412-07081-2, pp: 194.

Grayton, B.D. and F.W.H. Beamish, 1977. Effects of feeding frequency on food intake, growth and body composition of rainbow trout Salmo gairdneri. Aquaculture, 11: 159-172. DOI: 10.1016/00448486(77)90073-4

Hung, S.S.O., K.F. Fynn-Aikins, P.B. Lutes and R.P. Xu, 1989. Ability of juvenile white sturgeon (Acipenser transmontunus) to utilize different carbohydrate sources. J. Nutr., 119: 727-733. http://jn.nutrition.org/cgi/content/abstract/119/5/727 
Hutchins, C.G., S.D. Rawles and D.M. Gatlin, 1998. Effects of dietary carbohydrate kind and level on growth, body composition and glycemic response of juvenile sunshine bass (Morone chrysops $\times$ M. saxatilis). Aquaculture, 161: 187-199. DOI: 10.1016/S0044-8486(97)00269-X

Kayano, Y., S. Yao, S. Yamamoto and H. Nakagawa, 1993. Effects of feeding frequency on the growth and body constituents of young red-spotted grouper, Epinephelus akaara. Aquaculture, 110: 271-278.

http://cat.inist.fr/?aModele $=$ afficheN\&cpsidt $=4654$ 392

Kono, H. and Y. Nose, 1971. Relationship between the amount of food taken and growth in fishes. I. Frequency of feeding for a maximum daily ration. Bull. Jap. Soc. Sci. Fish., 37: 169-173. http://rms1.agsearch.agropedia.affrc.go.jp/contents/ JASI/pdf/society/02-4449.pdf

Lee, S.M., K.D. Kim and S.P. Lall, 2003. Utilization of glucose, maltose, dextrin and cellulose by juvenile flounder (Paralichthys olivaceus). Aquaculture, 221: 427-438. DOI: 10.1016/S00448486(03)00061-9

Lin, D., 1991. Grass Carp, Ctenopharyngodon Idella. In: Handbook of Nutrient Requirements of Finfish, Wilson, R.P. (Ed.). CRC Press, Inc., Boca Raton, FL., USA., pp: 89-96.

Lin, J.H., Y. Cui, S.S.O. Hung and S.Y. Shiau, 1997. Effect of feeding strategy and carbohydrate source on carbohydrate utilization by white sturgeon (Acipenser transmontanus) and hybrid tilapia (Oreochromis niloticus $\times$ O. aureus). Aquaculture, 148: 201-211. DOI: 10.1016/S00448486(96)01420-2

Mihelakakis, A., C. Tsolkas and T. Yoshimatsu, 2002. Optimization of feeding rate for hatchery-produced juvenile gilthead sea bream Sparus aurata. J. World Aquac. Soc., 33: 169-175. DOI: 10.1111/j.1749-7345.2002.tb00491.x

Murai, T., T. Akiyama and T. Nose, 1983. Effects of glucose chain length of various carbohydrates and frequency of feeding on their utilization by fingerling carp. Bull. Jap. Sot. Sci. Fish., 49: 1607-1611. http://rms1.agsearch.agropedia.affrc.go.jp/contents/ JASI/pdf/society/28-0556.pdf

Ng, W.K., K.S. Lu, R. Hashim and A. Ali, 2000. Effects of feeding rate on growth, feed utilization and body composition of tropical bagrid catfish. Aquac. Int., 8: 19-29. DOI: 10.1023/A: 1009216831360
Pieper, A. and E. Pfeffer, 1980. Studies on the comparative efficiency of utilization of gross energy from some carbohydrates, proteins and fats by rainbow trout (Salmo gairneri. R). Aquaculture, 20: 323-332. DOI: 10.1016/0044-8486(80)90093-9

Piper, R.G., I.B. McElwain, L.E. Orme, J.P. McCraren, L.G. Fowler and J.R. Leonard, 1982. Fish Health Management. In: Fish Hatchery Management, Gary Wedemeyer, A. (Ed.). United States Department of the Interior, Fish and Wildlife Service, Washington, DC., pp: 264-344.

Rabe, J. and J.A. Brown, 2000. A pulse feeding strategy for rearing larval fish: an experiment with yellowtail flounder. Aquaculture, 191: 289-302. DOI: 10.1016/S0044-8486(00)00434-8

Rawles, S.D. and D.M. Gatlin, 1998. Carbohydrate utilization in striped bass (Morone saxatilis) and sunshine bass (Morone chrysops $\times$ M. saxatilis). Aquaculture, 161: 201-212. DOI: 10.1016/S00448486(97)00270-6

Thia-Eng, C. and T. Seng-Keh, 1978. Effects of feeding frequency on the growth of young estuary grouper, Epinephelus tauvina (Forskal), cultured in floating netcages. Aquaculture, 14: 31-43. DOI: 10.1016/0044-8486(78)90138-2

Tian, L.X., Y.J. Liu and S.S.O. Hung, 2004. Utilization of glucose and cornstarch by juvenile grass carp. North Am. J. Aquac., 66: 141-145. DOI: 10.1577/A03-040.1

Tung, P.H. and S.Y. Shiau, 1991. Effects of meal frequency on growth perfotmance of hybrid tilapia, Oreochromis niloticus $\times O$. aureus, fed different carbohydrate diets. Aquaculture, 92: 343-350. http://cat.inist.fr/?aModele $=$ afficheN\&cpsidt $=4511$ 630

Wilson, R.P. and W.E. Poe, 1987. Apparent inability of channel catfish to utilize dietary mono-and disaccharides as energy source. J. Nutr., 117: 280-285. http://jn.nutrition.org/cgi/content/abstract/117/2/28 0

Wilson, R.P., 1994. Utilization of dietary carbohydrate by fish. Aquaculture, 124: 67-80. http://cat.inist.fr/?aModele $=$ afficheN\&cpsidt $=4193$ 375 